\title{
The Impact of the Scientific Approach and Teacher Work Motivation on the Critical Thinking Skills of Early Childhood in Kalidoni District, Palembang City
}

\author{
Ressy Riezki Chairani ${ }^{1 *}$, Happy Fitria ${ }^{2}$, Achmad Wahidy ${ }^{2}$
}

\author{
${ }^{1}$ Paramount School Palembang \\ ${ }^{2}$ Universitas PGRI Palembang \\ *Corresponding author. Email: ressyriezki@gmail.com
}

\begin{abstract}
This study describes the scientific approach's effect, teacher motivation, on early childhood critical thinking skills in Kalidoni. The method used is quantitative with a population of 80 samples. The data collection used questionnaires, observation, and documentary analysis techniques. Then, the data analysis used descriptive analysis, simple and multiple regression by using the IBM SPSS. The results showed (1) a partial influence between the scientific approach of critical thinking skills as evidenced by the value of $t$ count $>t$ table or 2.867>1.98397. (2) there was a partial and significant influence between teacher motivation of critical thinking skills as evidenced by the value of $t$ count $>t$ table or $8,457>1.98397$. (3) there is a simultaneous influence between the scientific approach, teacher motivation of critical thinking skills as evidenced by the value of $\mathrm{f}$ count $>\mathrm{t}$ table or $40,456>3.11$.
\end{abstract}

Keywords: Scientific, Motivation, Critical Thinking.

\section{INTRODUCTION}

\subsection{Background}

Every human needs education in their lives because education plays a vital role in shaping the mindset and making an individual's horizon more developed. Early Childhood Education is an effort that is expected to improve all their potentials, namely religious values, language, cognitive, physical motor, social-emotional, and art. Early Childhood Education aims to stimulate, guide, nurture, and help children lay the foundation towards developing attitudes, knowledge, skills, and creativity needed by children to adapt to the environment and for the children's growth and development further [1].

According to the facts/phenomena, the scientific approach learning can be explained by logical thinking, inspires students to think critically, creatively, analyze and be precise in identifying, understanding, and solving problems [2]

The scientific approach teaches children to find new knowledge, solve problems, think critically, and create creativity to assist them to comprehend the world, gather and process information as the primary keys for children learning to think critically. Learning with a scientific approach is focused on heartening children to find out from various sources over direct observation by the students themselves (student center) and not just being told (teacher center) [3]

Cognitive abilities that children need to hone from an early age are their thinking abilities. The definition of thinking ability is the ability to use reason to consider, decide, analyze, and do something well and carefully based on considerations or references [4]. One part of high-level cognitive abilities is critical thinking. The specific objectives of Early Childhood Education are so that children can think critically, give reasons, solve problems and find causal relationships [5]

Therefore, critical thinking skills are essential to be developed in early childhood. Critical thinking skills can be taught to early childhood using materials and methods that follow the stages of children's thinking skills that are still concrete. Critical thinking skills can lead children to make decisions appropriately, carefully, 
systematically, logically, and consider various points of view.

The scientific approach is not interpreted as learning science. Still, it uses a scientific process in learning activities that emphasizes aspects of direct activities that involve all the five senses whose function is as a conductor so that children can ask questions. After the questioning process has been stimulated well, it is hoped that the child can connect the results of old experiences with new experiences (associations). As reinforcement, the child experiments, and the final stage is to unify several abilities by communicating (reporting). This is supported by the research journal, which states that the scientific approach to learning is essential because it can foster and develop creativity, imagination, and ideas, including religious and moral values, cognitive, language, social, emotional, art motoric physics [6]. Based on the preliminary observations, the researcher found that most of the children's critical thinking abilities were still low. This is because the learning activities carried out are still centered on the teacher. The teacher provides explanations, and the child only listens without stimulating the child to think and explore in learning activities actively. The method used is more lecturing so that children get bored easily and are less actively engaged in every learning activity. During the question-and-answer activity, it was seen that only a few children responded to the teacher's questions. Also, it seems that some children are not enthusiastic about speaking or expressing their ideas. Teachers' motivation to develop professionalism (the ability to carry out learning) is still low because teachers in the field carrying out learning are limited to carrying out activities as they are. Some teachers do not master using a scientific approach to confuse teachers in carrying out learning with a scientific approach. Many teachers experience difficulties in carrying out this scientific approach arising from the lack of teacher preparation in teaching and teachers' low work motivation in increasing their knowledge of the scientific approach. A teacher should develop his professionalism, among others: performance in carrying out fun learning, student-centered learning, and learning that can improve critical thinking skills.

\subsection{Theoretical Review}

\subsubsection{Scientific Approach}

The age of 0 - 6 years is a golden period in the range of a child's development. This period is also known as the golden age. At this time, a child will grow very extraordinary in terms of emotional, cognitive, physical, motor, and psychosocial child development in a universal or comprehensive process in all aspects. Therefore, proposing stimulation also needs to take place comprehensively [7].
For this reason, the 2013 Curriculum for Early Childhood Education promotes children's learning methods so that they have competency attitudes, knowledge, and skills resulting from children's investigations into their environment through a scientific approach. This learning process is created to actively build competency attitudes, knowledge, and skills, ask questions, gather information, reason, and communicate.

The scientific approach is also designed to construct concepts, laws, or principles actively in deep stages such as to identify problems). Then, formulate problems, formulate hypotheses, collect data with various methods, analyze data, conclusions, and interconnect the concepts or principles set up [8].

Learning with a scientific approach is that students can understand and understand independently through the learning stages and teacher guidance to become more effective because learning is student-centered [9].

\subsubsection{Teacher Work Motivation}

The word motivation comes from the Latin "movere" which means to move. This term means to encourage, direct human behavior. Motivation comes from the word motive, which can be interpreted as an individual's power, which causes the individual to act or act [10]. The results showed that the principal's strategy in maximizing facilities and the teachers' role in improving the learning quality to be effective. The teachers became more motivated to provide educational and meaningful learning [11].

\subsubsection{Critical Thinking}

Thinking is the ability to analyze, criticize and reach conclusions based on inference or careful consideration. Learning is the effect of thought [12]. Critical thinking is a mental process to analyze or evaluate [13]. Critical thinking skills are a series of mental activities in analyzing or assessing clear and directed information. There is a reinforcement of the reasons for believing something and the implications of that belief. Critical thinking skills are essential in education because they can improve cognitive abilities and improve children's thinking power. Critical thinking should be nurtured from an early age. Educating children to get used to critical thinking will help children actively build selfdefense against attacks on information around them.

\subsection{Objective of the Study}

The purpose of this study is to determine the effect of a scientific approach and teacher work motivation on early childhood critical thinking skills in the Kalidoni sub-district in Palembang City. 


\section{METHODS}

The approach used in this study was descriptive quantitative. The population in the study was 100 Kindergarten teachers in Kalidoni District. From the sampling, 80 people were obtained. The sampling technique used in this research was the Isaac and Michael formula [14]. In this study, the researchers used the data collection techniques such as questionnaires, observation, and documentary analysis. Data collected using a Likert scale model. Simple regression analysis and multiple regression using SPSS for Windows version 25.00 were used as the data analysis techniques.

This study used multiple regression analysis, which aims to define the effect of two variables, the independent of dependent variables. Where this research looks for the influence of the scientific approach

(X1) and teacher work motivation (X2) as independent variables, with the critical thinking skills of Early Childhood (Y) as the dependent variable, either simultaneously or simultaneously. This research method uses partial and simultaneous regression methods. Hypothesis testing is done to determine the influence or relationship between the independent and dependent variables, where one of the independent variables is controlled [15]

\section{RESULTS AND DISCUSSION}

\subsection{Finding}

\subsubsection{The Influence of the Scientific Approach to Early Childhood Critical Thinking Skills}

The scientific approach's relationship model to aspects of critical thinking skills is expressed in the regression equation $\mathrm{Y}=19.053+0.826 \mathrm{X} 1$. Based on the scientific approach's significance test for early childhood thinking skills in the Kalidoni sub-district of Palembang City. The t count value is $7.414>$ the $t$ table price is 1.9900 where the $t$ value is more than the $t$ table, and the significance value is 0.000 less than 0.05 . Hol is accepted so that there is a significant influence between the scientific approaches to thinking skills of early childhood in Kalidoni sub-district, Palembang City.

\begin{tabular}{|l|l|r|r|r|r|r|}
\hline \multicolumn{2}{|l|}{} & \multicolumn{2}{|c|}{$\begin{array}{c}\text { Unstandardized } \\
\text { Coefficients }\end{array}$} & $\begin{array}{c}\text { Standardized } \\
\text { Coefficients }\end{array}$ & $\mathrm{t}$ & Sig. \\
\hline \multicolumn{2}{|l|}{} & \multicolumn{1}{|c|}{ B } & Std. Error & Beta & & \\
\hline \multirow{2}{*}{1} & (Constant) & 19.053 & 8.968 & & 2.124 & 0.037 \\
\cline { 2 - 7 } & $\begin{array}{l}\text { Scientific } \\
\text { Approach }\end{array}$ & 0.826 & 0.111 & 0.643 & 7.414 & 0.000 \\
\hline
\end{tabular}

\section{Table 1 Coefficient Scientific Approach}

\subsubsection{The effect of teacher work motivation on}

\section{Early Childhood Thinking Skills}

The model of the relationship between teacher motivation and teacher work performance is expressed in the form of the regression equation $\mathrm{Y}=11.461+$ $0.896 \mathrm{X} 2$. The regression equation significance test can be presented. Based on the significance test of the teacher's motivation variable on children thinking skills at an early age in Kalidoni sub-district, Palembang City, the $t$ value is $8,457>$ the $t$ table price is 1.9900 where the $t$ value is more than the $t$ table. The significance value is 0.000 less than 0.05 , so Ho1 is accepted so that there is a significant influence between motivation teachers of early childhood thinking skills in Kalidoni sub-district, Palembang

City.

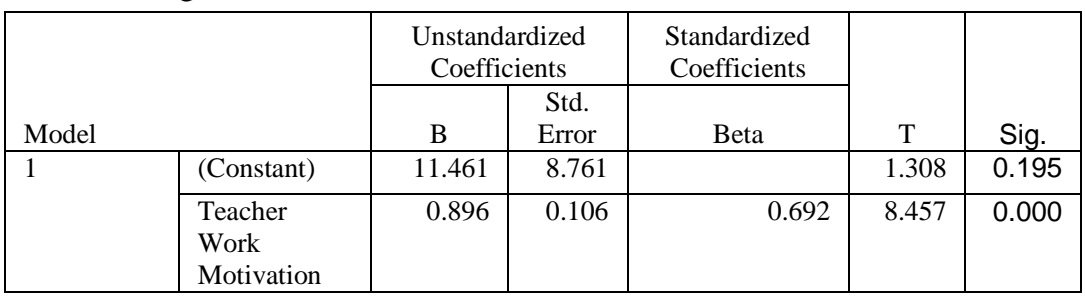

Tabel 2 Teacher Motivation Coefficient

\subsubsection{The Effect of Scientific Approach and Teacher Work Motivation on Early Childhood Critical Thinking Skills Aspects}

The model of the relationship between the scientific approach and teacher motivation towards early childhood thinking skills is expressed in the form of the regression equation $\mathrm{Y}=5.143+0.621 \mathrm{X} 1+0.361 \mathrm{X} 2$. This means that early childhood skills will experience a positive increase with the scientific approach and teacher motivation. 


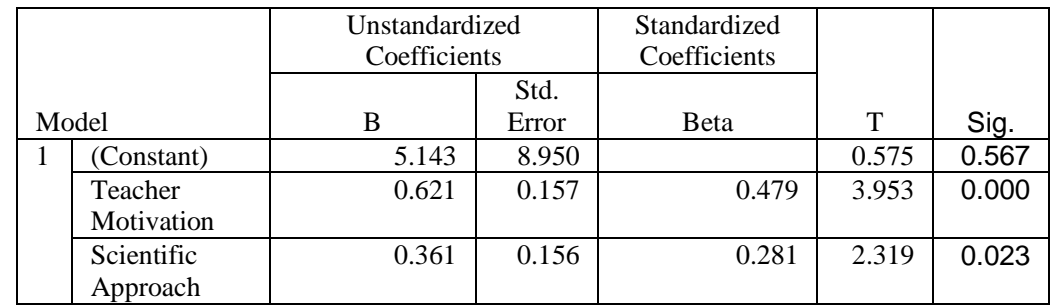

Tabel 3 Coefficient Scientific Approach and Teacher Motivation

\subsection{Discussion}

Based on the test results, it could be seen that the scientific approach variable has a regression coefficient value of 0.005 and the $t$ value of 2.867. The $\mathrm{T}$ Table of $\mathrm{N}=100$ is 1.98397 . The value of $\mathrm{t}$ count $>$ from $\mathrm{t}$ table or 2.867> 1.98397 so that the scientific approach affects early childhood thinking skills. While the significance level is smaller than the specified level of significance, namely $0.000<0.05$. This shows that the scientific approach was partially and significantly influential on critical thinking skills of early childhood

From the test results above, it could be seen that the teacher work motivation variable has a regression coefficient value of 0,000 and the t-count value of 8,457 . The $\mathrm{T}$ Table value of $\mathrm{N}=80$ is 1.9900 . The value of $t$ count $>t$ table or $8.457>1.9900$ so that the teacher's work motivation affects early childhood's critical thinking skills. Meanwhile, the significance level is greater than the predetermined significance level, which is $0.00<0.05$. This shows that teacher work mitigation partially and significantly affects early childhood critical thinking skills

The table above shows that the variable scientific approach and teacher work motivation have a regression coefficient value of 0.000 and a calculated $f$ value of 40.456. The value of $\mathrm{f}$ Table is obtained with the formula df $1=\mathrm{k}-1$, df $2=\mathrm{n}-\mathrm{k}$, this study has 3 variables so df $1=3-1=2$, the number of samples is 80 so that df $2=80-3=77$ and the value of $\mathrm{f}$ is obtained. The table is 3.11. So the value of $f$ count $>t$ Table or 40.456> 3.11. While the significance level is greater than the specified level of significance, namely 0.000 $<0.05$. The scientific approach and teacher motivation affect children's critical thinking skills. This matter. This means the initial hypothesis was rejected, and the second hypothesis was accepted.

\section{CONCLUSION}

The scientific approach and teacher work motivation simultaneously influence (together) the critical thinking skills aspects of early childhood in Kalidoni District, Palembang City, so it can be concluded that the first hypothesis was accepted. This is evidenced by the calculated $f$ value of $40.456>$ the $f$ table price of 3.11 .
The calculated $\mathrm{f}$ price is greater than the $\mathrm{f}$ table and a significance value of 0.000 , which is less than 0.005 , so Ho3 is accepted. There was a significant effect between the scientific approach and teacher motivation on early childhood thinking skills in Kalidoni District, Palembang City.

Scientific learning is intended to understand students in understanding, recognizing various materials by using a scientific approach. The information could come from anywhere and anytime. It does not depend on direct communication from the teacher. The scientific approach teaches children to find new knowledge, solve problems, think critically, and create creativity to help them comprehend the world, gather and process information as the basic keys for children learning to think critically. Work motivation is not only in economic interests but also in the form of a psychological need to do more active work. Work motivation for a teacher will usually be reflected in various activities and even achievements to be achieved. Teacher work motivation is nothing but a process carried out to mobilize teachers so that their behavior can be directed at real efforts to achieve the stated goals. This research also follows the research entitled The Effect of Work Environment and Work Motivation on High School Teachers' Performance in Muara Padang District. This study's findings are (1) The work environment influences teachers in carrying out their main tasks. (2) Motivation is an inner and outer encouragement of a teacher to carry out learning, hoping that learning objectives can be achieved. (3) The work environment and work motivation of teachers affect teacher performance [6]

The purpose of sharpening critical thinking skills in children is to educate children to communicate their thoughts, solve problems, and sort out the information received. Also, by being taught critical thinking from an early age, children are expected to be more conscientious, not easily give up, and be responsible.

Critical thinking skills are essential in education because they can improve children's thinking power and improve cognitive abilities. Critical thinking should be nurtured from an early age. Educating children to get used to critical thinking will help children actively build 
self-defense against attacks from information around them [13].

\section{ACKNOWLEDGMENT}

Thanks are given to Kindergarten teachers in Kalidoni Subdistrict, Palembang City, Chancellor of Palembang PGRI University, Director of Postgraduate PGRI Palembang University, and Chair of the PGRI Palembang University Education Management Masters Study Program. They have helped in completing this article which is a product of the thesis. Thank you also to the PGRI Palembang University Postgraduate students' friends and all those who have helped write and publish this journal.

\section{REFERENCES}

[1] Wahyudi, Penilaian Perkembangan Anak Usia Dini. Bandung: Refika Aditama. 2011.

[2] A. Majid, Pembelajaran Tematik terpadu. Bandung: Rosda Karya. 2014.

[3] Suyadi. Implemetasi dan Inovasi Kurikulum Paud 2013 (Pembelajaran Berbasis Multiple Intelegence). Bandung: PT Remaja Rosdakarya. 2014

[4] A. Yus, Model Pendidikan Anak Usia Dini. Jakarta.: Prenada Media. 2015.

[5] H. Rahman, Konsep Dasar Pendidikan Anak Usia Dini. Yogyakarta: PGTK Press. 2015.
[6] C. P. Eka, "Peningkatan Kemampuan Berpikir Kritis Pada Anak Usia Dini Melalui Bermain Maze.," Jurnal Pendidik. Anak Usia, vol. 7, no. 3, pp. 260-272. 2016.

[7] H. Indrijati, Psikologi Perkembangan dan Pendidikan Anak Usia Dini, Sebuah Bunga Rampai. Jakarta.: Prenada Media Grup. 2017.

[9] M. Hosnan, Pendekatan Saintifik \& Konseptual Dalam Pembelajaran Abad 21. Bogor: PG Ghalia Indonesia. 2014.

[10] Dewi., Kurikulum Berbasis Kompetensi: konsep, Karakter dan Implemetasi. Bandung: Rosda Karya. 2015.

[11] Uno, Hamzah B. \& Nina Lamatenggo., Teori Kinerja dan Pengukurannya. Jakarta.: Bumi Aksara. 2012.

[12] Trianto, T., \& Triwulan, T., Sertifikasi Guru dan Upaya Peningkatan Kualifikasi, Kompetensi dan Kesejahteraan. Jakarta.: Prestasi Pustaka. 2017.

[13] Suliah, Harapan,E., Arafat.,Y., "Headmaster's Strategy To Maximizes Using Infrastructure And Teachers' Role To Improve Learning Quality In Elementary School International," J. Sci. Technol. Res., vol. 8, no. 2. 2019.

[14] F. Faiz, thinking Skill : Pengantar Menuju Berpikir Kritis. Yogyakarta: Press. 2012.

[15] Sugiyono., Metode Penelitian Kuantitatif, Kualitatif dan R\&D. Bandung: PT Alfabet. 2016 